Journal of Social Sciences 8 (1): 13-15, 2012

ISSN 1549-3652

(C) 2012 Science Publications

\title{
Development Model to Improve the Quality of Academic Administration: A Case Study
}

\author{
Tawee Puengphai, Sakthai Surakitborworn and Wittaya Areerat \\ Department of Educational Management, Faculty of Education, \\ Rajabhat University, Mahasarakham, Thailand
}

\begin{abstract}
Problem statement: Academic teaching and learning of Ban Nongkham Borkaeowittaya School were not consistent with the current change to allow students to learn in accordance with the educational reform. Students could not be developed to their full potential. Most teaching methods still revolved around the teachers and lacked the learning encouragement of students with a variety of methods. Purpose: (1) to study the problems and the need to create and develop a model to improve the quality of academic administration of Ban Nongkham Borkaeowittaya School, Roi Et Educational Service Area Office $(3,2)$ to create and develop a model to improve the quality of academic administration of Ban Nongkham Borkaeowittaya School, Roi Et Educational Service Area Office 3, (3) to try and evaluate the model to improve the quality of academic administration of Ban Nongkham Borkaeowittaya School, Roi Et Educational Service Area Office 3 and 4) to evaluate the satisfaction of the model to improve the quality of academic administration of Ban Nongkham Borkaeowittaya School, Roi Et Educational Service Area Office 3 by school administrators, teachers, students and school board of directors. Approach: Qualitative research methodology used was an operational research according to the concept of McTaggart (1988). Data was collected using questionnaires and the minutes of conference from a group of 30 people. Data verification was done by a triangular technique. The result was presented by a descriptive analysis. Results: (1) For the study of current academic administration status of Ban Nongkham Borkaeowittaya School, Roi Et Educational Service Area Office 3, the result of the analysis of the opinions on academic administration in practice of 30 school administrators, teachers, students and school directors was "moderate", (2) To create and develop a model in which the implementation begins with the analysis of relevant factors, supporting school's policy and context, problem of requirement and concepts, theories and research related documents in order to determine a strategic development according to the quality development process of demming (PDCA) to assess quality of a school. The audit by experts found that the model is appropriate for implementation with a high score, 3) A comparison of the development of academic achievement of students in Primary School Level 3 (NT) and Level 6 (O-NET) between academic year 2551 and 2552 found that the achievement was higher. (4) For the satisfaction of relevant parties regarding the model to improve the quality of academic administration of Ban Nongkham Borkaeowittaya School, it was found that school administrators, teachers, board of directors and student have a high level satisfaction. Conclusion: The development model to improve the quality of academic administration: A case study of Ban Nongkham Borkaeowittaya School can improve students effectively and every relevant party is satisfied.
\end{abstract}

Key words: Development model, academic administration

\section{INTRODUCTION}

The improvement of the school system is crucial to the improvement of the quality of students, teachers, administrators and schools. The approach to improve the quality of school's academic administration will require a clear, effective and practical format.
Therefore, the educational resources such as teachers and educational personnel which are important part in educational administration must be developed to have the knowledge and skills for effective teaching and learning to respond to the needs of the people. In providing education to students, finding an appropriated format of academic development, which is the core of

Corresponding author: Tawee Puengphai, Department of Educational Management, Faculty of Education, Rajabhat University, Mahasarakham, Thailand 
the academic administration of school that corresponds to students' need, is crucial and very important.

\section{MATERIALS AND METHODS}

The research method used was an operational research according to the concept of McTaggart. The research was conducted in 2 spirals, each consisting of the following four steps; planning, action, observation and reflection. Each step was implemented according to PDCA. Data was obtained by specific selection method from the target group consisting of 1 school director, 8 teachers, 9 members of the school board of directors and 12 students of Ban Nongkham Borkaeo wittaya School, academic year 2008 for a total of 30 participants. The study findings were presented by means of a descriptive analysis.

\section{RESULTS}

The study of current status of academic administration studies of Ban Nongkham Borkaeowittaya School, Roi Et Educational Service Area Office 3 can be classified as follows:

The result of the analysis of the opinions on academic administration in practice of 30 school administrators, teachers, students and school directors was "moderate". When it was broken down into classification, the result was "moderate" in all aspects which were; (1) the development of curriculum (2) the development of the learning process (3) evaluation, assessment and credit transfer (4) research to improve the quality of education (5) development of innovation and technology for education (6) development of learning resources (7) educational supervision (8) educational counseling (9) development of quality assurance system in school (10) promotion of knowledge (11) coordinate a cooperation in the academic development with other educational institutions and other organizations (12) promote and support academic matter for individuals, families, organizations, agencies and other institutions that provide education.

The model to improve the quality of academic administration of Ban Nongkham Borkaeowittaya School, academic year 2552 was the following:

The development of curriculum: It was found that the target group used the process of brainstorming to study the problems and obstacles of the development of curriculum and find the approach to solve them together. Assigning tasks to various individuals was successful.

The development of learning process: The main task of teachers was to write lesson plans that meet the curriculum and learning expectation by emphasizing actual condition. There was a teaching demonstration process for teachers in various subject groups which emphasized the demonstration that relied on mutual cooperation.

The testing, evaluation and credit transfer: The conference agreed on the guidelines regarding the creation and quality checking of the tools prior to being used as the measurement and evaluation of students. At the end of the academic year, there was an academic exhibition in which parents would participate in the evaluation of students' projects. Community and organizations were invited to participate to comment on the academic administration of the school.

Research to improve the quality of education: The research was used to solve the problems of students' learning impairs. The beginning of the research was to record the students' achievements after teaching in order to learn the details of weakness of students. Thereafter, innovative media was used to solve the problems or encourage students to obtain higher achievement.

The development of innovation media and technology for education: The conference agreed that participants explored innovation media in their classroom, gathered, recorded and improved them for usage in the teaching. A central committee was responsible for gathering information from different classes and recorded them in order to prepare the media to be in working condition. For the lack of computers, the school board considered setting up a donation drive to try to help in this regard.

Development of learning resources: The school had learning resources related to the improvement of the quality of education both in schools and local communities in the local and nearby education areas. There were documents about the learning resources that were distributed to teachers, other schools, individuals, families, organizations, agencies and other institutions. The school was both a network and learning resources.

The supervision of education: There was a system of academic and teaching and learning supervision in school in various forms that was appropriate for the school.

Educational counseling: Providing a system of counseling for academic and vocational educations by linking it to the network of assistance system.

Development of school's internal quality assurance system: Creating a structure of the organization to support the system of internal quality assurance and specifying the assessment requirement, successful target, the standard index of the ministry and successful 
goal of the school district according to the rules and procedures of assessment by National Education Standards and Quality Assessment.

The promotion of academic knowledge: Supporting the community's academic study to provide knowledge, reinforce ideas, techniques and academic skills for the development of professional skills and quality of life. Local community participated in academic activities.

The cooperation in the academic development with other educational institutions and organizations: Cooperated with government and private educational institutions and local administrations in both the basic and higher education in the local and other educational areas study to build a network of academic development cooperation with other organizations.

Individual, family, organization, agencies and other educational institutions: Preparation of educational information as well as providing support and encouragement of academic subject to individuals, families, organizations, agencies and other education institutions.

The result of the creation and development of the model to improve the quality of academic administration of Ban Nongkham Borkaeowittaya School, Roi Et Educational Service Area Office 3: The process began with the study of factors that support the policy and context of the school which was found to be appropriate for usage with "high" score

Trial and evaluation of the model to improve the quality of academic administration of Ban Nongkham Borkaeowittaya School, Roi Et Educational Service Area Office 3: 4.1 Comparison of the development of academic achievement of students in Primary School Level 3 (NT) and Level 6 (O-NET) between academic year 2551 and 2552 found that the achievement was higher.

For the satisfaction of relevant parties regarding the model to improve the quality of academic administration of Ban Nongkham Borkaeowittaya School, it was found that school administrators, teachers, board of directors and student have a high level satisfaction (Ziadat, 2011).

\section{DISCUSSION}

The study of current status of academic administration of Ban Nongkham Borkaeowittaya School, Roi Et Educational Service Area Office 3 according to the scope of 12 issues found that the development of curriculum by strategic brainstorming analyzed current status and issues and provided opportunities for target groups to participate in curriculum development. We found that the analysis of important features and issues that should be improved to use as information on developing a curriculum revealed the strength such as the unity of all personnel to support the education of the school. Students had discipline and leaders of the communities cooperated in all aspects that the school required. The usage of brainstorming in academic development resulted in the effective educational administration of school (McTaggart, 1988).

\section{CONCLUSION}

The created model to improve the quality of academic administration of Ban Nongkham Borkaeowittaya School, Roi Et Educational Service Area Office 3 was found to be the model that began with the analysis of factors that support the school's policy and context, the status of requirement issues and the ideas, theories, documents and related researches to determine the strategy according to the quality Development Process of Demming (PDCA) to assess the quality of the school. The review of the model found that it was appropriate for adoption by with the "high" score. All relevant parties are satisfied (Lahiri, 2010).

\section{ACKNOWLEDGEMENTS}

The researchers express their sincere appreciation for all of support provided.

\section{REFERENCES}

McTaggart, R. 1988. The Action Research Reader. 3rd Edn., Deakin University, ISBN: 073000564X, pp: 430.

Lahiri, S., 2010. Assessing the environmental attitude among pupil teachers in relation to responsible environmental behavior: A leap towards sustainable development. J. Soc. Sci., 7: 33-41. DOI: $10.3844 /$ jssp.2011.33.41

Ziadat, A.H., 2011. Assessing the performance of jordanian educational counselors in the environment of private and government schools toward gifted students. Am. J. Applied Sci., 8: 164171. DOI: 10.3844/ajassp.2011.164.171. 